\title{
THE EFFECTIVENESS OF REINSTATEMENT
}

\section{AS A PUBLIC POLICY REMEDY: THE KOHLER CASE}

\author{
JOHN E. DROTNING and DAVID B. LIPSKY
}

\section{$I^{\prime}$} $\mathrm{N} 1952$, nearly twenty years after the American Federation of Labor tried to organize the Kohler Company, the United Automobile Workers won bargaining rights. ${ }^{1}$ But its success was ephemeral. Victory at the polls turned to defeat at the bargaining table in 1954

This article is concerned with two aspects of the NLRB reinstatement remedy as applied in the famous Kohler case: (I) how effective the remedy was, particularly in terms of the number of employees who returned to Kohler under its protection, and (2) what factors, in order of significance, affected a worker's decision to return. The authors find the remedy was effective, since about 40 percent of those workers who received reinstatement offers accepted them. Regression and discriminant analyses of the variables affecting the decision to return confirm the thinking of labor market economists that the most disadvantaged worker (lower paid, older, less educated, less skilled, married, with children and with a nonworking wife) was most likely to return to a Kohler job. Recommendations are offered for improving the efficacy of the reinstatement remedy, with emphasis on adding a penalty cost to its back-pay feature.

John E. Drotning is associate professor of industrial relations and organization, State University of New York at Buffalo. David B. Lipsky is assistant professor of industrial relations, State University of New York at Buffalo. The authors express appreciation to Gordon Teeter and Brad Powell of Purdue University and Sam Giancarlo, State University of New York at Buffalo, for their assistance and to Harry Brickman, National Labor Relations Board, for his encouragement of the study. They also acknowledge a debt of gratitude to the Computing Center and the Industrial Relations Seminar at Buffalo.-EDiror when the auto workers struck Kohler in a last-ditch effort to force management to bargain in good faith. So began the longest industrial dispute in modern times. $^{2}$

It was not until August 1960, over six years after the strike began, that the National Labor Relations Board found Kohler guilty of bad-faith bargaining. The Board ordered Kohler to bargain in good faith with the employees and to reinstate workers who applied for their old jobs. ${ }^{3}$ This raises a significant question. How effective is the present public policy remedy, especially in extended unfair labor practice strikes? This question is usually argued on the basis of logical deduction and legal precedent. In this article, the usual method of analysis is combined with an empirical investigation of the reinstatement remedy as it operated in the Kohler case. The effectiveness of the reinstatement remedy must be judged, in part, on its operational impact. How many workers were reinstated to their jobs? What factors were related to their decision to return to Kohler? The authors do not argue that

\footnotetext{
${ }^{1}$ Walter H. Uphoff, Kohler on Strike (Boston, Mass.: Beacon Press, 1966).

2Jack Barbash, "Ideology and the Kohler Strike," Wisconsin Law Review, Spring 1967, p. 468.
}

${ }^{3}$ Kohler Company 128 NLRB 1062 (1960). 
the percentage of workers accepting reinstatement, or their characteristics, are the only criteria-or even the best criteriain judging the effectiveness of reinstatement. They do argue that an empirical analysis of the impact of a public policy remedy employed with more traditional forms of analyses can best lead to an informed judgment on the question of effectiveness.

Before turning to an analysis of the data in the Kohler case, it is necessary to discuss the mechanics of the NLRB's reinstatement remedy, with and without the back-pay feature. Subsequent sections of the article discuss the source and nature of the data available, the more general dimensions of Kohler's courtordered offer and the workers' response, the general hypothesis underlying our empirical analysis, followed by the analysis itself-a statistical examination of the determinants of the strikers' response to reinstatement. Reinstatement is analyzed further in terms of its remedial intent or objective and a recommendation is made designed to improve the reinstatement remedy.

\section{Mechanics of the Reinstatement Remedy}

Reinstatement with or without back pay applies to (1) pro-union workers discharged during union organizing drives and to (2) strikers protesting their employers's bad-faith bargaining. The differences between the two situations are worth elaborating.

An organizing union usually tries to identify and use a small group of strongly pro-union workers in the unorganized plant. Once the campaign is on, these activities are visible to management and the work force. Some anti-union employers may fire organizers to intimidate the work force into voting against union representation. Such employers commit an $8(a)(3)^{4}$ unfair labor practice. Only a small number of employees have to be discharged from a plant during an organizing drive for the employer to defeat the union at the polls. ${ }^{5}$ These employees can complain individually or through a union and usually can get the National Labor Relations Board to require the employer to offer them reinstatement. Whether they accept it or not is another question. The discharged employee's response to the reinstatement offer is likely to depend on his perception of what his work life will be like after reinstatement. Will he be the victim of subtle coercion or will he be accepted as though he had never struck? Moreover, the character of work life must depend on whether the union won or lost bargaining rights. If the union lost, the reinstated union activist is not likely to be welcomed back to his old job by a hostile employer. ${ }^{6}$

Reinstatement also applies when the employer refuses to bargain in good faith with the union. In such cases, the workers may protest their employer's bad-faith conduct by striking. In contrast to economic strikers, these unfair labor practice strikers must be taken back if they apply for unconditional reinstatement. If, however, the employer is innocent, unfair labor practice strikers become economic strikers and run the commensurate risk of permanent job loss. The critical point

4Section 8(a)(3) of the National Labor Relations Act prohibits an employer from discriminating against employees to discourage membership in a union.

${ }^{5}$ John E. Drotning, "The Union Representation Election: A Study in Persuasion," Monthly Labor Review, Vol. 88, No. 8 (August 1965), pp. 938-943.

${ }^{6}$ See Leslie Aspin, "A Study of Reinstatement Under the National Labor Relations Act" (Ph.D. dissertation, Massachusetts Institute of Technology, 1966); and Bernard Samoff, "The Impact of Taft Hartley Job Discrimination Victories," Industrial Relations, Vol. 4, No. 3 (May 1965), pp. 77-94. 
in such cases is whether the NLRB regional office issues a complaint. ${ }^{7}$ If it does, the risk of permanent job loss by unfair labor practice strikers is reduced significantly since complaints are usually upheld by the Board and/or courts.

Assume an employer bargains in bad faith and his employees strike. The strikers may have sufficient economic strength to force the employer to bargain in good faith. If so, presumably they will return to work under a new contract. If they cannot impose significant costs on their employer, however, they can (1) continue to walk the picket line, (2) find other work, or (3) apply for reinstatement. The union, of course, can press the unfair

\footnotetext{
${ }^{\tau}$ After the Board issues a complaint, the union may tell the workers to return to work while it presses the charge. Any employer who does not accept the strikers' applications may incur large back-pay costs.
}

labor practice charge regardless of its members' decisions. ${ }^{8}$

If the strikers apply for unconditional reinstatement, the employer can (1) reject their applications, (2) make an inadequate job offer, or (3) make a bona fide offer. If either (1) or (2) occurs, back pay begins to accumulate, although the process is not as simple as it sounds. Consider an employer who bargains in bad faith and is struck by his employees. Each side faces certain alternatives, and the decisions made by the parties set the stage for further tactical moves. The figure illustrates the sequential decision making which can take place.

The employer may capitulate and bargain in good faith at any point during the strike; capitulation may be dictated by any number of factors, including the

\footnotetext{
"This assumes that the complaints are "not reversed" by the Board and/or courts.
}

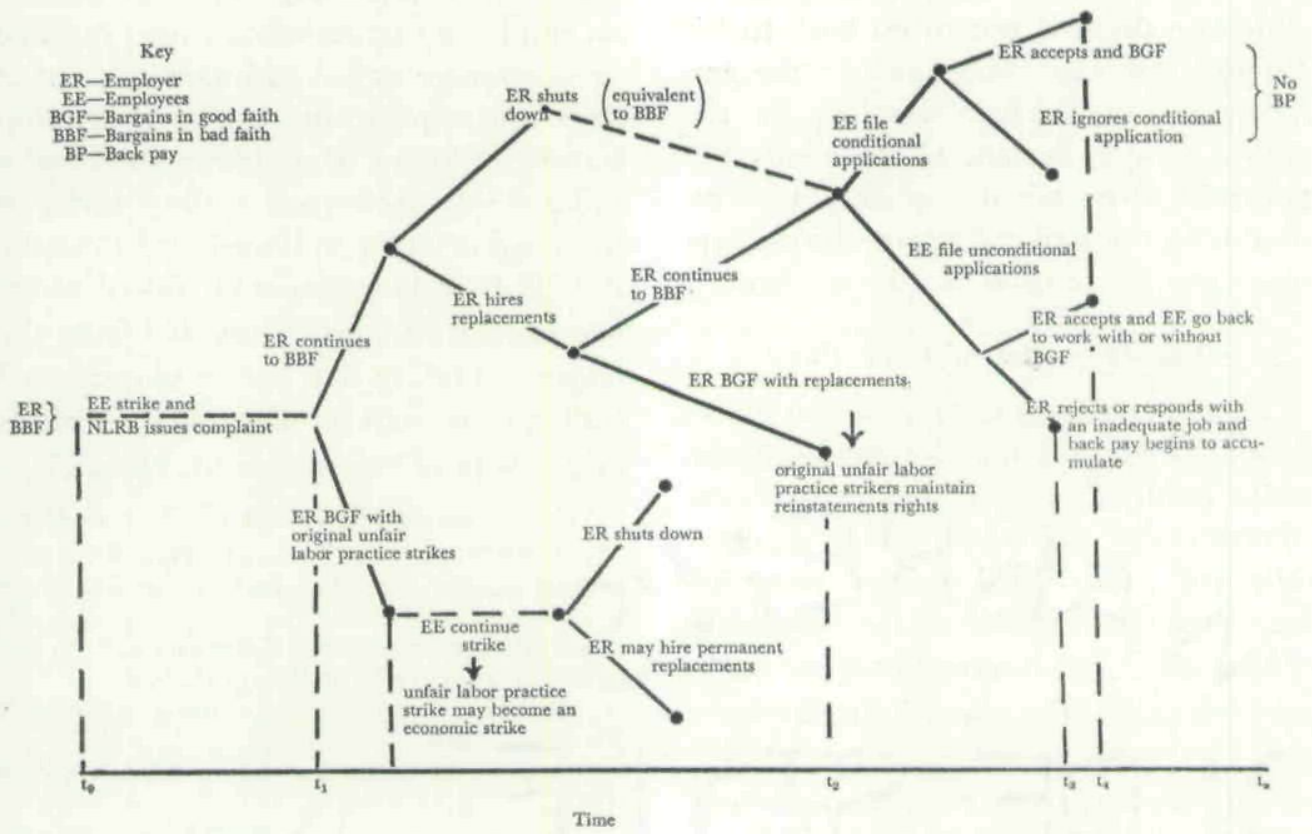

Figure 
unavailability of labor and nonlabor substitutes and the small size of his inventory. If the strikers shut the employer down, they have reason to stay out since they may force him to bargain in good faith. But if management hires replacements, the employees cannot impose significant costs on him and are forced to apply for reinstatement and to return to their old jobs or to seek alternatives. Moreover, if the employee conditions his application, the employer need not reply. If the application is unconditional, however, and management makes an unacceptable response, back pay begins and can be collected even if the applicant never returns to his old job. For example, if a striker applies for unconditional reinstatement and the employer rejects him or offers him an inadequate job, the striker may decide not to return to the old plant before the employer makes a legitimate response. In such cases, the striker may collect back pay from the time of his application to the point at which he decided not to go back to his old job. But one thing is clear, the employer has no financial liability for the period $t_{3}-t_{0}$ (where $t_{3}$ represents the point in time when the employer responds to the strikers' unconditional applications for reinstatement-see figure).

\section{The Question of Back Pay}

There is a strong sentiment and precedent against holding employers financially liable to strikers before they unconditionally apply for reinstatement. Originally, the Board ordered reinstatement without considering the possibility of back pay, ${ }^{9}$ but it soon added the backpay feature. ${ }^{10}$ The Board, in an early

${ }^{\circ}$ Columbian Enameling and Stamping Company, 1 NLRB 181 (1936); Foster Brothers Manufacturing Company, Inc., 1 NLRB 880 (1936).

${ }^{10}$ Sunshine Hosiery Mills, 1 NLRB 664 (1936); comment, said, "When employees voluntarily go on strike, even if in protest of unfair labor practices, it has been our policy not to award them back pay during the strike."11 It elaborated on this when it refused to accept an argument that back pay should be awarded employees caught in an employer unfair labor practice strike by saying:

We do not agree to award back pay to such strikers, no matter how flagrant an employer's unfair labor practice might be. Such a policy would, in our opinion not only encourage but also place a premium upon resort by employees to industrial strikes and the interruption of commerce in order to obtain redress of wrongs, rather than promote recourse to the orderly administrative process estabblished by the Act. Inasmuch as it is incumbent upon the Board to formulate and adopt such remedies as will effectuate the policies of the Act, we shall adhere to our practice of denying backpay to unfair labor practice strikers under circumstances such as those in this case. ${ }^{12}$

This statement was reinforced in 1961 when the Board said, "The Act forbids an employer to discriminate to encourage or discourage union membership, but it does not require an employer to reimburse employees who choose voluntarily to be absent from work in the exercise of their rights under sections 7 and 13 of the Act." 13 In a later decision, Board member John H. Fanning dissented from the majority finding that the employer owed back pay to strikers who rejected piecemeal offers of reinstatement. He said:

While such employees do not lose their reinstatement rights where, as here, their employer has unlawfully refused to reinstate

Black Diamond Steamship Corporation, 3 NLRB 84 (1937), enforced 94 F. 2d 875 (C.A. 2).

ii American Manufacturing Company, 5 NLRB 443 at 467 (1938).

${ }^{12}$ Volney Felt Mills, Inc., 70 NLRB 908 at 910 (1946).

${ }^{13}$ Northern Virginia Sun Publishing Company, 134 NLRB 1007 (1961). 
their fellow employees, their election to engage in concerted activity is protected from reprisal, but not financed by the employer. The Act does not protect an employee from loss of wages as a result of a strike even though the strike was caused by an unfair labor practice. An employee who prefers concerted activity to the status of "strikebreaker" cannot sup at both tables. He cannot be unavailable for work to put economic pressure on his employer to rectify a wrong and at the same time receive full pay for the job from which he has voluntarily absented himself. ${ }^{14}$

This was the posture of the Kohler strikers. They did not apply for reinstatement until 1960, immediately after the Board's finding, and so were not eligible for back pay for the six-year period between 1954 and 1960 .

\section{The Data}

The data are contained in two separate sets of microfilm-more than 9,000 feet in all. One set contains biographic and employment information on each Kohler striker up to 1954 . The other set comprises employment information from 1960-1965. In some cases, it was possible to get employment information on the strikers for the period 1954-1960 as well. The films contained about 1,800 names. There was fairly complete information on some of the people, less on others, and almost none on still others. But the good far outweighs the bad. It is a massive amount of information of the kind which would have been impossible to get without the help of the National Labor Relations Board (both in Washington, D.C. and Milwaukee). Moreover, many of the people were interviewed by the NLRB between 1960 and 1965, and this record is included in the microfilms.

Also important are the affidavits of some of the strikers. These give an inside

\footnotetext{
${ }^{14}$ Robert S. Abbot Publishing Company, 139 NLRB 1328, fn. 4, p. 1330 (1962).
}

look at the cost of such a strike to the workers. No statistics can illustrate what it must be like for a fifty-five year old man nearing twenty-five years of service and a gold watch (which was important to a Kohler worker) to be out of work for five to eight years.

Since the information on each person varies, the population size varies depending on the variables under examination. The two distinct microfilm sources, initially coded on two separate decks of punch cards, were merged into one deck to facilitate computer analysis.

\section{The Reinstatement Offer and Strikers' Response}

There were about 1,780 employees named on the UAW's application for reinstatement in 1960 . The company offered reinstatement to all except those categorized as: (1) strikers discharged for misbehavior (about 77), (2) strikers who retired (about 108), and (3) strikers who had secured a release (about 82). Releases were short statements signed by employees stating that they intended to sever permanently their employment relationship with Kohler. The release was designed, the authors believe, to distinguish between strikers and voluntary quitters. If the latter lack reinstatement rights, Kohler could minimize back pay penalty costs. Releases were occasionally requested by strikers looking for alternative employment but more often were required by the worker's prospective employer. Special Master Judge Edward M. DuQuaine initially ruled that Kohler was not required to make an offer of reinstatement to workers who had retired or had obtained a release. ${ }^{15}$ Subsequent-

\footnotetext{
${ }^{15}$ Special Master's Report by Edward M. DuQuaine for U. S. District Court of Appeals for the District of Columbia Circuit, NLRB v. Kohler Company, No. 16, 031, Feb. 1, 1965.
} 
ly, the court's review of this ruling resulted in its reversal. ${ }^{16}$

The company made two additional offers of reinstatement. In September 1964 the Board, in its supplemental decision, found that fifty-seven strikers were improperly discharged for picket-line activity. ${ }^{17}$ The company, at or near the end of the month, made an offer of reinstatement to the fifty-seven strikers. Kohler made a third offer in February 1965, following Judge DuQuaine's ruling that the company had been guilty of contempt. About 111 additional workers were then offered reinstatement.

In total, the three offers covered about 1,685 workers. Less than 10 percent of the workers for whom the union made application failed to receive an offer.

How many strikers accepted reinstatement? According to Walter Uphoff, the Kohler Company sent letters to about 1,400 striking employees in 1960 offering reinstatement. The company "declined to reveal how many had accepted reinstatement," but a UAW spokesman estimated the figure to be about $1,000.18$

We have information on the offeracceptance question for only 1,150 workers-about two thirds of the population of strikers. In this sample, 956 strikers received offers and 456 accepted reinstatement (47.6 percent). It is likely that only a small proportion of the strikers for whom no information was available accepted reinstatement, since this group includes those the NLRB could not reach, those who had died, etc. If about 40 percent of those who received offers did accept reinstatement, no more than 690 returned to their jobs at Kohler between 1960 and 1965.

There were essentially three reasons

${ }^{10}$ NLRB v. Kohler, 52LC 16, 617 (1965).

${ }^{17}$ Kohler Company, 148 NLRB 1434 (1964).

${ }^{18}$ Uphoff, op. cit., p. 305. given by the Kohler workers for refusing the reinstatement offer: nearly 20 percent rejected on the ground that the job they were currently holding paid a higher wage; about 14 percent rejected because there was no union contract at Kohler; and about 10 percent rejected because Kohler had put its enamel and brass divisions on a short (thirty-two hour) workweek. Most of the remaining workers did not give a specific reason for rejecting the reinstatement offer, although health was apparently another important factor. ${ }^{19}$

\section{The General Hypothesis}

Our central concern here is to identify those characteristics which were associated with an employee's acceptance of the reinstatement offer. A wide range of personal, social, and economic variables which might help to discriminate between those who accepted reinstatement and those who did not were examined. It is readily acknowledged that, given the heavily emotional overtones of the Kohler strike, a worker's decision to accept reinstatement might be the result of complex psychological forces not readily subject to measurement or quantification. Instead, focus was put on measurable characteristics which, on the basis of accumulated labor market research, are associated with a worker's ability to operate successfully in the labor market.

Specifically, the general hypothesis under which the investigation was carried out is as follows: Strikers who were most likely to experience difficulty being reabsorbed into the labor force were considered to be the most likely candidates to accept reinstatement. Past studies of workers displaced because of plant

\footnotetext{
${ }^{10}$ Silicosis apparently was a frequent consequence of Kohler employment. Many of the older strikers visited Rocky Knoll Sanitorium.
} 
shutdowns and technological change pointed to characteristics related to a displaced worker's reemployment experience. We know on the basis of research conducted by Myers, Shultz, Weber, Ferman, Franke, Wilcock, and others, that older, lower wage, more senior, less educated, and less skilled workers are likely to have the most difficult labor market experience after displacement. ${ }^{20}$ We make the important assumption that the labor market experience of workers discharged for union activity approximates that of workers displaced for more ordinary economic reasons, and accordingly hypothesize that, among other variables, age, wage, education, marital status, number of dependents, seniority, and skill level were important determinants of acceptance of reinstatement by the Kohler striker.

The assumption that the labor market experience of illegally discharged workers is similar to that of workers displaced for economic reasons is probably not valid if the unfair labor strike is quickly terminated and the order of reinstatement issued within a relatively short period of time. In fact, however, the average time elapsed in processing section 8 (a) $(5)^{21}$ cases from filing to closing is 1,020 days, or nearly three years, for those brought through the court order

${ }^{\circ \circ}$ Charles A. Myers and George P. Shultz, The Dynamics of a Labor Market (New York: Prentice-Hall, 1951); Richard C. Wilcock and Walter H. Franke, Unwanted Workers (Glencoe, IIl.: The Free Press, 1963); William Haber, Louis A. Ferman, and James R. Hudson, The Impact of Technological Change (Kalamazoo, Mich.: W. E. Upjohn Institute for Employment Research, 1963); George Shultz and Arnold Weber, Strategies for the Displaced Worker (New York: Harper and Row, 1966).

${ }^{2}$ NLRA, "Section 8-It shall be an unfair labor practice for an employer...(5) To refuse to bargain collectively with the representatives of his employees, subject to the provisions of section 9(a)." stage. ${ }^{22}$ The longer a strike, the stronger the forces which compel the striker to find alternative work. If the employer hires replacements and commits obvious unfair labor practices, the worker may realize very quickly that the line between being on strike and being discharged is a thin one.

While our evidence on the experience of the strikers between 1954 and 1960 is fragmentary, it indicates that about 60 percent of the Kohler strikers had found new jobs within two years of the commencement of the strike, i.e., by April 1956; and that nearly 90 percent had found new jobs within four years. (These figures do not include the several hundred workers who returned to Kohler in response to the company's "back-towork movement.") The labor market reabsorption rates for Kohler strikers (as well as for other strikers) are no doubt much slower than the reabsorption rates for economically displaced workers, other things being equal. Nevertheless, if the scanty information we have on the strikers between 1954 and 1960 is at all accurate, it indicates that the great majority of Kohler strikers had at least one job and were otherwise active in the labor market fully four years before the 1960 reinstatement offer. From this it appears that the labor market experience of Kohler strikers, especially by 1960 , roughly approximates that of other types of displaced workers.

\section{Factors Related to Acceptance of the Reinstatement Offer}

Specific factors affect a worker's decision to accept or reject reinstatement. This sample deals with 922 Kohler strikers for whom nearly complete information was available.

\footnotetext{
${ }^{29}$ Information supplied by the NLRB.
} 
Age and sex. Only a small proportion (4 percent) of the Kohler labor force was female. More than 60 percent of the women accepted reinstatement compared to about 40 percent of the men. However, there were too few women in the sample from which to draw significant conclusions; therefore, the sex variable was not included in the analysis.

Table 1 shows that the percentage of Kohler workers in each age category accepting reinstatement (the acceptance rate) increased with age and the percentage rejecting decreased. Of the strikers over 40 years of age in 1960, 48 percent accepted reinstatement compared to 31 percent of those 40 and younger; chi-square tests show that the association between age and reinstatement is significant at better than the .01 level. Moreover, the average age of those accepting reinstatement is 41.2 years compared to 37.7 for those rejecting the company's offer. This difference is statistically significant at the .01 level.

Table 1. Strikers' Response to Reinstatement versus Age.

\begin{tabular}{|c|c|c|c|c|}
\hline \multirow{2}{*}{ Age in 1960} & \multicolumn{2}{|c|}{ Accept } & \multicolumn{2}{|c|}{ Reject } \\
\hline & No. & $\%$ & No. & $\%$ \\
\hline Under $30 \ldots$ & 13 & 29.5 & 31 & 70.5 \\
\hline $31-35 \ldots \ldots$ & 32 & 26.4 & 89 & 73.6 \\
\hline $36-40 \ldots \ldots$ & 54 & 34.2 & 104 & 65.8 \\
\hline $41-45 \ldots \ldots$ & 74 & 42.5 & 100 & 57.5 \\
\hline $46-50 \ldots \ldots$ & 78 & 50.6 & 76 & 49.4 \\
\hline $51-55 \ldots \ldots$ & 65 & 49.6 & 66 & 50.4 \\
\hline $56-60 \ldots \ldots$ & 35 & 47.9 & 38 & 52.1 \\
\hline $64-65 \ldots \ldots$ & 27 & 62.8 & 16 & 37.2 \\
\hline $66-70 \ldots \ldots$ & 8 & 42.1 & 11 & 57.9 \\
\hline 70 and over & 3 & 60.0 & 2 & 40.0 \\
\hline Total.... & 389 & 42.2 & 533 & 57.8 \\
\hline Mean age & 41.2 & & 37.7 & \\
\hline
\end{tabular}

Note: $\mathrm{X}^{2}=35.9 ; \mathrm{df}=9 ; 0<.01$.

Marital status and number of dependent children. Fortunately, the data also allowed distinction between married men with and without a working wife. Table 2 shows the relationship between marital status and the strikers' response to reinstatement. Approximately 21 percent of the strikers' wives were working in 1960.

Table 2. Strikers' Response to Reinstatement versus Marital Status and Labor Force Status of Wife.

\begin{tabular}{|c|c|c|c|c|}
\hline \multirow{2}{*}{ Status of Wife } & \multicolumn{2}{|c|}{ Accept } & \multicolumn{2}{|c|}{ Reject } \\
\hline & No. & $\%$ & No. & $\%$ \\
\hline $\begin{array}{l}\text { Single, widowed, } \\
\text { divorced.......... }\end{array}$ & 43 & 38.4 & 69 & 61.6 \\
\hline $\begin{array}{l}\text { Married, wife not } \\
\text { working in } 1960 \ldots\end{array}$ & 288 & 46.8 & 327 & 53.2 \\
\hline $\begin{array}{l}\text { Married, wife work- } \\
\text { ing in } 1960 \ldots \ldots \ldots \\
\text { Total. ........... }\end{array}$ & $\begin{array}{r}58 \\
389\end{array}$ & $\begin{array}{l}29.7 \\
42.2\end{array}$ & $\begin{array}{l}137 \\
533\end{array}$ & $\begin{array}{l}70.3 \\
57.8\end{array}$ \\
\hline
\end{tabular}

Note: $\mathrm{X}^{2}=18.5 ; \mathrm{df}=2 ; \mathrm{p}<.01$.

Married men whose wives were not working were much more likely to accept reinstatement than strikers with working wives. Single, divorced, and widowed men (roughly 13 percent of the sample) fall into a middle ground in terms of acceptance rate.

The number of dependent children also exerted an influence on a striker's decision on reinstatement, as shown in Table 3. The larger the number of dependent children, the more likely a striker was to accept Kohler's offer in 1960. The chi-square test is again significant at less than .01. For example, only about 33 percent of the strikers with no children accepted reinstatement as compared to 70 percent with families of five or more. Moreover, the mean number of dependent children of strikers rejecting reinstatement is 1.5 , whereas it is nearly 2.0 for those returning to their old jobs 
Table 3. Strikers' Response to Reinstatement versus Number of Dependent Children.

\begin{tabular}{|c|c|c|c|c|}
\hline \multirow{2}{*}{$\begin{array}{c}\text { Number of Dependent } \\
\text { Children }\end{array}$} & \multicolumn{2}{|c|}{ Accept } & \multicolumn{2}{|c|}{ Reject } \\
\hline & No. & $\%$ & No. & $\%$ \\
\hline $0, \ldots \ldots \ldots \ldots \ldots \ldots$ & 79 & 33.5 & 157 & 66.5 \\
\hline $1, \ldots \ldots \ldots+\ldots, \ldots$ & 99 & 41.8 & 138 & 58.2 \\
\hline $2 \ldots \ldots \ldots \ldots \ldots \ldots$ & 104 & 43.7 & 134 & 56.3 \\
\hline $3, \ldots \ldots \ldots \ldots \ldots \ldots$ & 53 & 46.1 & 62 & 53.9 \\
\hline $4 \ldots \ldots \ldots \ldots \ldots \ldots$ & 27 & 55.1 & 22 & 44.9 \\
\hline 5 or more. .......... & 14 & 70.0 & 6 & 30.0 \\
\hline Total............ & 376 & 42.0 & 519 & 58.0 \\
\hline $\begin{array}{l}\text { Mean number of } \\
\text { dependent } \\
\text { children........ }\end{array}$ & 1.9 & & 1.5 & \\
\hline
\end{tabular}

Note: $\mathrm{X}^{2}=18.005 ; \mathrm{df}=5 ; \mathrm{p}<.01$.

(difference is significant at less than .01; $\mathrm{t}=3.03)$.

Table 4 shows the effect of both marital status (including the labor force status of the wife) and number of dependent children on the strikers' response to reinstatement. For example, for strikers with no dependent children, 37.9 percent of the single, divorced, and widowed accepted reinstatement; 31.5 percent of those married without a working wife accepted reinstatement; and 26.7 percent of those married with a working wife accepted reinstatement. The relationship between marital status and reinstatement for strikers with zero dependents is not significant, as judged by the chi-square test.

There is a strong association, however, between marital status and reinstatement for workers with one or two dependent children. The chi-square test is significant at better than the .01 level. Table 4 shows that differences are particularly significant between men with and men without working wives and those with one or two dependent children. Strikers whose wives were not working were much more likely to accept reinstatement. Because of the relatively few strikers with three or more children, a significance level of any real value for the association between reinstatement and marital status, distinguishing men with and without working wives, could not be determined.

It can be noted, therefore, that whether the strikers were married and had a working wife seems to have been a major determinant of their response to reinstatement if the household had one or two children. In households with no dependents, there was a tendency to reject reinstatement, regardless of marital status

Table 4. Strikers' Response to Reinstatement versus Marital Status and Number of Dependent Children.

\begin{tabular}{|c|c|c|c|c|c|c|c|c|c|c|c|c|}
\hline \multirow{3}{*}{$\begin{array}{c}\text { Number of } \\
\text { Dependent Children }\end{array}$} & \multicolumn{4}{|c|}{ Single, Divorced, Widowed } & \multicolumn{4}{|c|}{$\begin{array}{c}\text { Married, Wife Not Working } \\
\text { in } 1960\end{array}$} & \multicolumn{4}{|c|}{$\begin{array}{c}\text { Married, Wife Working } \\
\text { in } 1960\end{array}$} \\
\hline & \multicolumn{2}{|c|}{ Accept } & \multicolumn{2}{|c|}{ Reject } & \multicolumn{2}{|c|}{ Accept } & \multicolumn{2}{|c|}{ Reject } & \multicolumn{2}{|c|}{ Accept } & \multicolumn{2}{|c|}{ Reject } \\
\hline & $\mathcal{N} o$ & $\%$ & No. & $\%$ & No. & $\%$ & No. & $\%$ & No. & $\%$ & No. & $\%$ \\
\hline & 36 & 37.9 & 59 & 62.1 & 35 & 31.5 & 76 & 68.5 & 8 & 26.7 & 22 & 73.3 \\
\hline $1 \ldots \ldots \ldots \ldots \ldots$ & 3 & 33.3 & 6 & 66.7 & 81 & 49.4 & 83 & 50.6 & 15 & 23.4 & 49 & 76.6 \\
\hline $2 \ldots \ldots \ldots \ldots \ldots$ & 1 & 20.0 & 4 & 80.0 & 84 & 50.3 & 83 & 49.7 & 19 & 28.8 & 47 & 71.2 \\
\hline $3 \ldots \ldots \ldots \ldots \ldots$ & 2 & 100.0 & 0 & 0.0 & 44 & 45.4 & 53 & 54.6 & 7 & 43.8 & 9 & 56.3 \\
\hline $4 \ldots \ldots \ldots \ldots \ldots$ & 1 & 100.0 & 0 & 0.0 & 24 & 57.1 & 18 & 42.9 & 2 & 33.3 & 4 & 66.7 \\
\hline 5 or more. . . . . . & 0 & 0.0 & 0 & 0.0 & 11 & 64.7 & 6 & 35.3 & 3 & 100.0 & 0 & 0.0 \\
\hline Total . . . . . . . & 43 & 38.4 & 69 & 61.6 & 279 & 46.7 & 319 & 53.3 & 54 & 29.2 & 131 & 70.8 \\
\hline
\end{tabular}


or labor force status of the wife. In households with three or more dependents, there was a tendency to accept reinstatement regardless of marital status or labor force status of the wife.

\section{Influence of Workers' Education, Seniority, and Wages}

Education. Studies of the labor market have shown the influence of education on the reemployment experience of displaced workers; i.e., less educated workers clearly have a more difficult time finding alternative employment than the more educated. It would follow, then, that the less educated Kohler worker would be the most likely to accept the reinstatement offer. Table 5 shows the marked difference in acceptance rates between high school graduates and those without a high school diploma.

Table 5. Strikers' Response to Reinstatement Offer versus Education.*

\begin{tabular}{|c|c|c|c|c|}
\hline \multirow{2}{*}{ Years of Schooling } & \multicolumn{2}{|c|}{ Accept } & \multicolumn{2}{|c|}{ Reject } \\
\hline & No. & $\%$ & No. & $\%$ \\
\hline $0-8 \ldots \ldots \ldots \ldots \ldots$ & 205 & 47.1 & 230 & 52.9 \\
\hline $9-11 \ldots \ldots \ldots \ldots$ & 88 & 45.6 & 114 & 56.4 \\
\hline $12 \ldots \ldots \ldots \ldots \ldots$ & 92 & 33.8 & 180 & 66.2 \\
\hline 13 or more........ & 4 & 30.8 & 9 & 69.2 \\
\hline Total........... & 389 & 42.2 & 533 & 57.8 \\
\hline $\begin{array}{l}\text { Mean years of } \\
\text { school } \dagger \ldots \ldots .\end{array}$ & 9.3 & & 9.7 & \\
\hline
\end{tabular}

Nearly half (47 percent) of the Kohler workers in Table 5 had completed fewer than nine years of school; only about 1.4 percent had gone beyond high school. Just under 70 percent of the small number with more than a high school education rejected reinstatement; their alternative opportunities made a return to Kohler unattractive. In general, the mean level of education was less for those accepting reinstatement than for those rejecting-9.28 years to 9.73 years respectively, and this difference is significant at less than the .01 level.

Before the 1954 strike, almost all the Kohler strikers (about 90 percent) had been employed in semiskilled work. It is difficult to differentiate between them on the basis of skill, except, perhaps by their level of education.

Seniority. One might expect that workers with long years of service at Kohler would be more likely to accept reinstatement than short-service workers. In other collective bargaining relationships, high seniority usually means that the worker has accumulated certain nonvested job-related benefits. It may also imply that a worker is more "loyal" to his employer and more attached to his job. At Kohler, however, long service did not necessarily mean added tangible benefits for the worker. The Kohler employee had seniority rights only in his department. The company refused to recognize any limits on interdepartmental transfers, and workers frequently found that their seniority was dissolved by an intraplant job change. Layoffs were not related to seniority, nor were pensions. Seniority was taken into consideration on promotions only when ability of the candidates was equal. There was no "posting and bidding system" on job advancements; Kohler firmly believed that workers should be rewarded on the basis of merit alone. Disagreement over seniority rights was one of the major causes of the 1954 strike.

Despite the weaknesses in Kohler's seniority system, Table 6 demonstrates that workers with longer service were more likely to accept reinstatement. The mean seniority for workers accepting re- 
Table 6. Strikers' Response to Reinstatement versus Seniority.*

\begin{tabular}{|c|c|c|c|c|}
\hline \multirow{2}{*}{$\begin{array}{c}\text { Years of Seniority at } \\
\text { Time of Strike }\end{array}$} & \multicolumn{2}{|c|}{ Accept } & \multicolumn{2}{|c|}{ Reject } \\
\hline & No. & $\%$ & No. & $\%$ \\
\hline $0-4 \ldots \ldots \ldots \ldots \ldots$ & 98 & 32.2 & 206 & 67.8 \\
\hline $5-9 \ldots \ldots \ldots \ldots$ & 75 & 36.6 & 130 & 63.4 \\
\hline $10-14 \ldots \ldots \ldots \ldots$ & 75 & 53.6 & 65 & 46.4 \\
\hline $15-19 \ldots \ldots \ldots \ldots$ & 72 & 49.3 & 74 & 50.7 \\
\hline $20-24 \ldots \ldots \ldots \ldots$ & 12 & 63.2 & 7 & 36.8 \\
\hline $25-29 \ldots \ldots \ldots \ldots$ & 31 & 48.4 & 33 & 51.6 \\
\hline $30-34, \ldots \ldots \ldots \ldots$ & 21 & 61.8 & 13 & 38.2 \\
\hline $35-39 \ldots \ldots \ldots \ldots$ & 2 & 33.3 & 4 & 66.7 \\
\hline 40 or more. . . . . . & 3 & 75.0 & 1 & 25.0 \\
\hline Total........... & 389 & 42.2 & 533 & 57.8 \\
\hline Mean years & & & & \\
\hline seniority $\nmid \ldots . .$. & 13.5 & & 10.5 & \\
\hline
\end{tabular}

instatement was 13.5 years, three years more than those rejecting; and this is highly significant. The chi-square test on the association is also significant at better than the .01 level.

What accounts for the relationship between seniority and reinstatement? It is true, of course, that there is no way of telling how much stronger the relationship might have been if seniority had been more meaningful for the strikers. Also, seniority is highly correlated with age (the correlation coefficient is 0.71 ). And the use of discriminant analysisdiscussed in a subsequent section-reveals age to be a stronger predictor of the striker's reinstatement decision than seniority. It might also be argued that more senior employees had a tendency to accept reinstatement not because seniority meant a great deal to them in 1960, but because of their expectation that the establishment of positive collective bargaining at Kohler would lead to the enhancement of the seniority system.

Wages. Wage data available on the Kohler employees is limited principally to hourly rates paid to the workers in 1954 prior to the strike. ${ }^{23}$

The median hourly wage of the Kohler worker before the 1954 strike was approximately $\$ 1.80$. Sixty percent of the Kohler strikers had been making between $\$ 1.50$ and $\$ 2.00$ an hour. The hourly wage offer made to workers accepting reinstatement in 1960 was not much higher than the hourly wages paid in 1954; however, Kohler did increase wages by about 16 percent between April 5, 1954 and November 24, 1958. Of more importance, though, and as noted earlier, Kohler cut the workweek to thirty-two hours principally to insure that as many as possible of those workers hired after 1954 could continue in employment. As a result, returning strikers had weekly earnings which were not much more than 80 percent of their 1954 level.

It is clear from Table 7 that there was a strong relationship between the strik-

Table 7. Strikers' Response to Reinstatement versus 1954 Hourly Wage Rate.

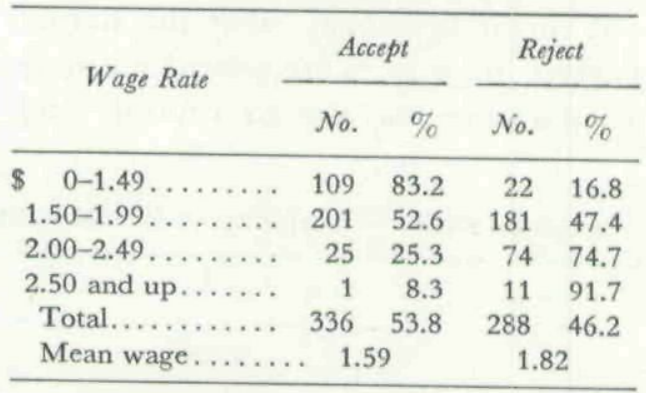

Note: $\mathrm{X}^{2}=88.2 ; \mathrm{df}=3 ; \mathrm{p}<.01$.

er's hourly wage rate in 1954 and his decision to accept reinstatement. For

\footnotetext{
${ }^{23}$ The useable sample in this section is reduced to 624 . In this smaller sample, 53.8 percent accepted reinstatement. Comparing the smaller sample of acceptances with the larger sample used in preceding sections, however, reveals no significant differences between the two groups in terms of the means and variances of the variables analyzed in this article. The same is true of the larger and smaller samples of rejections.
} 
example, over 83 percent of the workers in the low-wage category accepted reinstatement, whereas only 23.4 percent of those workers who had earned $\$ 2.00$ an hour or more in 1954 returned to Kohler in 1960. Moreover, the mean 1954 wage of those accepting reinstatement was $\$ .23$ an hour less than those rejecting the company's offer.

It is interesting to see how education affects the relation between wage level and reinstatement. Table 8 indicates that the chi-square test on the wage-reinstatement relation is highly significant within each of the three education categories. The same strong inverse relation between wage and percentage accepting reinstatement is still present, even when disaggregated by educational attainment. On the other hand, much of the significance of the education-reinstatement relation is eliminated by holding the wage rate constant; it disappears completely for those who had earned under $\$ 1.50$ an hour.

It might be thought that the Kohler workers' wage rates are related not only to education but also to seniority and age. Regressing wages on these variables, however, reveals no significant relation:

$$
\begin{gathered}
\mathrm{X}_{1}=1.87196-.00303 \mathrm{X}_{2}-.00375 \mathrm{X}_{3} \\
-.00146 \mathrm{X}_{4} \\
(.00181) \quad(.00630) \\
(.00181)
\end{gathered}
$$

$$
\mathrm{R}^{2}=.0163 \quad \mathrm{~F}=3.420
$$

The regression equation shows that less than 2 percent of the observed variation in the Kohler employees' 1954 wage rates $\left(\mathrm{X}_{1}\right)$ can be explained by age $\left(\mathrm{X}_{2}\right)$, education $\left(\mathrm{X}_{3}\right)$, and seniority $\left(\mathrm{X}_{4}\right)$. None of the regression coefficients is significant. Note that even the signs in the equation run counter to a priori expectations. Adding the variables of number of dependent children and marital status does nothing to improve the fit. Wage rates, therefore, appear to be virtually independent of the other variables examined in this analysis.

It may be that a better fit would be obtained if it were possible to use some better measure of earnings, rather than

\begin{tabular}{|c|c|c|c|c|c|c|c|c|c|c|c|c|c|}
\hline & \multirow{4}{*}{ Wage Rate } & \multicolumn{12}{|c|}{ Years of Schooling } \\
\hline & & \multicolumn{4}{|c|}{$0-8^{*}$} & \multicolumn{4}{|c|}{$9-11 \dagger$} & \multicolumn{4}{|c|}{$12 \ddagger$} \\
\hline & & \multicolumn{2}{|c|}{ Accept } & \multicolumn{2}{|c|}{ Reject } & \multicolumn{2}{|c|}{ Accept } & \multicolumn{2}{|c|}{ Reject } & \multicolumn{2}{|c|}{ Accept } & \multicolumn{2}{|c|}{ Reject } \\
\hline & & No. & $\%$ & No. & $\%$ & No. & $\%$ & No. & $\%$ & No. & $\%$ & No. & $\%$ \\
\hline$\$$ & $0-1.49 \ldots \ldots \ldots$ & 57 & 85.1 & 10 & 14.9 & 26 & 78.8 & 7 & 21.2 & 26 & 83.9 & 5 & 16.1 \\
\hline & $.50-1.99 \ldots \ldots \ldots$ & 105 & 59.3 & 72 & 40.7 & 46 & 54.1 & 39 & 45.9 & 46 & 41.1 & 66 & 58.9 \\
\hline & $00-2.49 \ldots \ldots \ldots$ & 15 & 29.4 & 36 & 70.6 & 5 & 27.8 & 13 & 72.2 & 5 & 16.7 & 25 & 83.3 \\
\hline & .50 and up..... & 1 & 20.0 & 4 & 80.0 & - & - & 2 & 100.0 & - & - & 5 & 100.0 \\
\hline & Total......... & 178 & 59.3 & 122 & 40.7 & 77 & 55.8 & 61 & 44.2 & 77 & 43.3 & 101 & 56.7 \\
\hline
\end{tabular}
the simple hourly wage rate. The apparent independence of the Kohler wage structure may reflect the company's ideo-

Table 8. Strikers' Response to Reinstatement by Wage Rate and Years of Schooling.

$* \mathrm{X}^{2}=40.5 ; \mathrm{p}<.01$.

$\dagger \mathrm{X}^{2}=15.4 ; \mathrm{p}<.01$.

$\ddagger \mathrm{X}^{2}=33.5 ; \mathrm{p}<.01$. 
logical commitment to individual initiative and the use of incentive payments.

\section{Discriminant Analysis}

Discriminant analysis was applied to the data in order to determine which linear combination of the variables examined best discriminates between those accepting and those rejecting reinstatement. Discriminant analysis is similar to regression analysis, except that regression analysis is most applicable to cases in which the dependent variable is continuous, whereas discriminant analysis is most applicable to cases in which the dependent variable is dichotomous (as here) or polychotomous. The technique is especially appropriate when one is not trying to determine whether or not two samples are from different populations, but rather when one is attempting to estimate how closely the characteristics of one subject resemble the characteristics of the group to which he belongs (or is likely to belong). The discriminant technique produces an equation, or function, which generates a "discriminant score," or index, for each subject. ${ }^{24}$ The higher or lower the score, the greater the likelihood that the subject belongs to one group as opposed to the other. If the function is capable of perfect discrimination, then the score it generates for each individual will place him within the group to which he, in fact, belongs. ${ }^{25}$

Table 9 presents the results of the discriminant analysis. It was necessary to use two randomly selected samples of strikers - 270 who had accepted reinstatement and 270 who had rejected-because of the limits on the sample size contained

${ }^{24} \mathrm{C}$. R. Rao, Linear Statistical Inference and Its Applications (New York: John Wiley, 1965), pp. 480-483, 487-493.

${ }^{25}$ See Gerhard Tintner, Econometrics (New York: John Wiley \& Sons Science Editions, 1965), pp. 96-102. in the canned computer program used in the analysis. The means are computed within each group for each variable. $\mathrm{D}^{2}$ is a measure of the weighted difference of the means, where the weights are the coefficients of the variables in the discriminant function. An F-value is computed using the values of $\mathrm{D}^{2}$, and the significance of the equations can be tested in the usual way. All of the twenty-two equations in Table 9 are significant at the 5 percent level or better. The equations are ordered on the basis of the number of strikers correctly predicted by the equations to be within either the acceptance group or the rejection group.

In the absence of any knowledge of the strikers, chance alone should permit us to predict the reinstatement decision for 50 percent of the strikers. Knowing the hourly wage rate allows prediction of the striker's decision in about 71 percent of the cases (equation 1). This is significantly better than chance. The addition of other variables to the discriminant equation, however, reduces the predictive power of the equations. For example, equation 2, in which age is combined with wage, predicts 70 percent of the strikers' decisions correctly-still significantly better than chance, but less powerful than wage alone! The most powerful discriminant equations, in the sense of predictive power, all contain the wage variable. The most powerful equation in the absence of the wage variable (equation 13) combines the other five variables and predicts 64 percent of the strikers' decisions correctly-7 percent less than the wage variable by itself, but still much better than chance.

When wage is excluded from the equations, age is the next strongest determinant of a striker's reinstatement decision. When both wage and age are excluded, seniority is the third strongest variable; 
Table 9. Discriminant Analysis.

\begin{tabular}{|c|c|c|c|c|c|c|c|c|c|}
\hline \multirow[b]{2}{*}{ Equation } & \multicolumn{6}{|c|}{ Coefficients } & \multirow[b]{2}{*}{$D^{2}$} & \multirow[b]{2}{*}{$F$} & \multirow[b]{2}{*}{$\begin{array}{c}\% \\
\text { Predicted } \\
\text { Correctly }\end{array}$} \\
\hline & $\begin{array}{l}\text { (7) } \\
\text { Age }\end{array}$ & $\begin{array}{c}\text { (2) } \\
\text { Marital } \\
\text { Status }\end{array}$ & $\begin{array}{c}\text { (3) } \\
\text { Number } \\
\text { of } \\
\text { Dependent } \\
\text { Children }\end{array}$ & $\begin{array}{c}(4) \\
\text { Education }\end{array}$ & $\begin{array}{c}\text { (5) } \\
\text { Seniority }\end{array}$ & $\begin{array}{c}\text { (6) } \\
\text { Wage, } 1954\end{array}$ & & & \\
\hline 1.. & & & & & & -.00060 & .75310 & 101.66811 & 70.74 \\
\hline $2 \ldots \ldots$ & .00008 & & & & & -.00059 & .92249 & 62.15208 & 70.00 \\
\hline $3 \ldots$. & .00008 & -.00009 & .00033 & .00003 & & -.00060 & .98724 & 26.45719 & 70.00 \\
\hline $4 \ldots$ & & & & -.00006 & .00006 & -.00059 & .85953 & 38.53506 & 69.63 \\
\hline $5 \ldots \ldots$ & & & .00034 & -.00004 & .00006 & -.00061 & .93796 & 31.47977 & 69.63 \\
\hline $6 \ldots$. & .00007 & & .00031 & .00003 & .00002 & -.00060 & .98931 & 26.51286 & 69.63 \\
\hline 7... & & -.00006 & .00036 & -.00004 & .00006 & -.00060 & .93907 & 25.16642 & 69.63 \\
\hline $8 \ldots \ldots$ & & & & -.00014 & & -.00060 & .77745 & 52.38036 & 69.26 \\
\hline $9 \ldots \ldots$ & & & & & .00007 & -.00059 & .85526 & 57.62268 & 69.26 \\
\hline $10 .$. & .00006 & & .00031 & & .00002 & -.00060 & .98842 & 33.17330 & 69.26 \\
\hline $11 .$. & .00007 & -.00009 & .00033 & .00003 & .00002 & -.00060 & .99157 & 22.10294 & 69.26 \\
\hline $12 \ldots \ldots$ & & & .00035 & -.00012 & & -.00062 & .85990 & 38.55146 & 67.41 \\
\hline $13 .$. & .00008 & -.00032 & .00030 & .00005 & .00002 & & .27028 & 7.24333 & 64.07 \\
\hline $14 \ldots \ldots$ & .00009 & & .00022 & .00004 & & & .23422 & 10.50076 & 62.96 \\
\hline $15 \ldots \ldots$ & .00007 & -.00031 & .00029 & & .00002 & & .26760 & 8.98118 & 61.85 \\
\hline $16 \ldots \ldots$ & .00008 & & .00022 & & & & .23250 & 15.66428 & 61.48 \\
\hline $17 \ldots \ldots$ & .00009 & -.00031 & .00029 & & & & .26038 & 11.67361 & 61.48 \\
\hline $18 \ldots \ldots$ & & & & & .00008 & & .13183 & 17.79730 & 61.11 \\
\hline $19 \ldots$ & .00009 & -.00017 & & & & & .21163 & 14.25847 & 61.11 \\
\hline $20 \ldots \ldots$ & .00009 & & & & & & .20190 & 27.25637 & 60.37 \\
\hline $21 \ldots \ldots$ & .00009 & & & .00004 & & & .20327 & 13.69528 & 58.89 \\
\hline $22 \ldots \ldots$ & .00007 & & & & .00002 & & .20767 & 13.99162 & 58.89 \\
\hline
\end{tabular}

by itself, it predicts 61 percent of the strikers' decisions correctly (equation 18). Because of the intercorrelation of age and seniority, however, when age is included in the equation, seniority loses much of its force.

The discriminant equation which includes the wage variable alone is the most powerful predictor, but this fact should not be interpreted to mean that the other variables are unimportant. First, as noted above, all the equations in Table 9 are significant, in the sense that they could not have arisen by chance alone. Second, the use of chi-square and means tests in earlier sections showed that each of the six variables is related to the striker's reinstatement decision.

\section{Summary}

The authors' general hypothesis-that the most disadvantaged worker in the labor market would be the most likely to accept Kohler's offer of reinstatement-is borne out by the evidence. Lower wage, older, less educated, less skilled workers 
with greater family obligations were the most likely workers to accept Kohler's court-ordered offer. ${ }^{26}$ It is known from the accumulated research on the operation of the labor market that these are the traits of workers who have the most difficult time finding reemployment after displacement. The market does not seem to afford them the protection it provides other workers. But in a sense, reinstatement does; it restores the disadvantaged to their jobs. Admittedly, they had a long wait, but eventually work became a reality. In this sense, the remedy was effective even though only 40 percent of all strikers offered jobs accepted. In other words, measuring the effectiveness of the reinstatement remedy in terms of the simple proportion who were restored to their jobs indicates that a minority elected to take advantge of the reinstatement offer; undoubtedly, this was not the intended result of the remedy's use. On the other hand, by examining the characteristics of those who returned, we have shown that the remedy did afford some protection for those strikers who were likely to be most adversely affected by an unfair labor practice strike.

Although the evidence tends to show that workers displaced for economic reasons and workers discharged after an unfair labor practice strike have similar experiences in the labor market, there are important differences between the two types of displaced workers, which include the following.

(1) The economically displaced worker knows immediately that he is permanently terminated and must reenter the labor market to find alternative employment. The worker caught in an unfair

\footnotetext{
${ }^{20} \mathrm{An}$ interesting implication of this is that employers in long unfair labor practice strikes incur the cost of losing their best men-the ones who do not return.
}

labor practice strike may expect a quick end to the strike or ultimate reinstatement, and this expectation may keep him from making a serious search for another job until he is finally convinced or compelled to do so by the circumstances of his displacement.

(2) The economically displaced worker often may expect remedial assistance from his employer in the form of transfer opportunities, retraining, severance pay, placement services, and the like upon his termination. Of course, this help would not be available to the worker replaced during an unfair labor practice strike.

(3) Public policy has been devised to aid the economically displaced worker. Aid includes unemployment compensation, retraining, and other manpower programs. Most of these programs are closed to strikers on the assumption that their lack of work is largely their own fault. ${ }^{27}$ This assumption may be diffcult to justify in the case of a worker caught in an unfair labor practice strike. These workers have an extended period of joblessness aggravated by their employer's unlawful actions.

Moreover, Kohler did not bargain with the union until June 1962, nearly two years after the Board had found the company guilty of bargaining in bad faith. As a result, the wages, hours, and working conditions which existed in 1954 prevailed until June 1962, when the UAW finally won a substantially improved oneyear contract. Since then, the UAW has negotiated six one-year contracts with

\footnotetext{
${ }^{27}$ An exception would be the unemployment compensation laws in New York and Rhode Island which permit strikers to collect unemployment after seven weeks on strike. See U. S. Department of Labor, Manpower Administration, Bureau of Employment Security, Comparison of State Unemployment Insurance Laws (Washington, G.P.O.: 1958), BES No. U-141, p. E-18.
} 
Kohler; and according to Raymond Majerus, Kohler workers' wages are now on a par with the wages of other employees in the organized sector of the plumbingware industry. ${ }^{28}$

These differences raise a general question: What is the remedial intent of reinstatement with or without back pay? Is it designed to (1) restore the status quo ante, (2) promote positive collective bargaining, (3) minimize industrial unrest, or (4) some combination of these? Board member Gerald Brown recently asked, "How is it possible to restore the situation to where it would have been if the good-faith bargaining required under the law had occurred 1 or 2 or 3 or more years before?"29 This seems to mean two things. First, how can legal or Board processes be accelerated to reduce the time between the issuance of a complaint and a Board order? And second, how can we make "the position(s) of the wronged parties the same as before the commission of a wrong." 30

\section{Recommendations}

It is always possible to speed up any bureaucratic process if one has sufficient funds. But the Board does not have unlimited funds to spend to become more efficient. The Board could streamline its administrative machinery to decrease case loads, but this would not decrease to any extent the time between a complaint and an order.

What about restoring the status quo?

\footnotetext{
${ }^{25}$ Telephone conversation with Raymond Majerus, International Representative of the UAW in Milwaukee, Jan. 17, 1968.

NSpeech given on Nov. 2, 1967 in Dallas, Texas, at the Fourteenth Annual Institute on Labor Law of the Southwestern Legal Foundation.

${ }^{30}$ Harry A. Millis and Emily C. Brown, From the Taft Hartley Act to the Wagner Act (Chicago, IIl.: The University of Chicago Press, 1950), p. 482 .
}

Is this even possible? Taken literally, one might be restoring the conditions just prior to an $8(a)(5)$ strike which in fact caused the strike, instead of restoring conditions which would lead to goodfaith bargaining. How can one restore what never existed! It seems more fruitful to take another tack; that is, instead of restoring the status quo ante, why not attempt to promote positive collective bargaining? This approach might minimize industrial unrest as an outgrowth of bad-faith bargaining.

An obvious solution would be to devise a remedy which encourages good-faith collective bargaining. One way to do this would be to increase the cost of bad-faith bargaining. The back-pay portion of the reinstatement remedy aims to compensate the unfair labor practice strikers (or 8 (a)(3) dischargees). In this sense the remedy is nonpunitive, not a private award for personal damages, but a sum given in the public interest in vindication of public rights. ${ }^{31}$ But if employers guilty of bad-faith bargaining must pay workers who protest such behavior, then awarding back pay is costly to them. From the employer's standpoint then, back pay is punitive, i.e., he pays for committing a wrong. ${ }^{32}$

The rational employer who must pay for his wrongs is likely to consider the costs of bad-faith bargaining. If the costs are greater than zero, they would logically tend to inhibit his propensity to engage in unfair labor practices. Increased costs, therefore, could lead to less bad-faith bargaining. If costs were increased infinitely, unfair labor practices would cease entirely, since any rational employer would prefer to stay in business than to commit an unfair labor

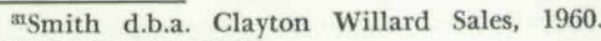
CCH NLRB P 18707.

${ }^{\text {sp }}$ Millis and Brown, op. cit., p. 483.
} 
practice and then be forced to cease operating. But this kind of remedy is unthinkable, since it certainly would not encourage "the practice and procedure of collective bargaining." 33 There may be some cost greater than zero and less than infinity, however, which would stimulate positive collective bargaining practices and minimize employer (and union) unfair labor practices. ${ }^{34}$

That the costs imposed on Kohler in the form of back pay were not sufficient to achieve desirable goals should be selfevident. Indeed, there is good reason to believe that the remedies employed by the Board in 8(a)(5) cases have not succeeded in discouraging employers from engaging in bad-faith bargaining. Section $8(a)(5)$ bargaining cases have increased significantly in recent years-from 1,311 cases in 1959 to 3,811 in $1966 . .^{35}$

One way of increasing the costs of badfaith bargaining is to require an employer to add to back pay the amount the employees might have gotten if the employer had bargained in good faith. ${ }^{36}$ For example, the Board might require that an employer found guilty of badfaith bargaining would have ninety days to come to terms with the union; if at the end of this period he does not comply

${ }^{{ }^{a}}$ National Labor Relations Act, sec. (1).

${ }^{3}$ A strong case can be made that behavior which is initially forced on unwilling parties eventually becomes accepted. See Milton Rokeach, The Open and Closed Mind (New York: Basic Books, 1960).

${ }^{5}$ NLRB, Annual Report, for fiscal years 1959 through 1966, Tables 1 and 2.

${ }^{*}$ See Ex-Cell-O Corp. v. UAW, 25-CA-2377. Recently, attorneys for the UAW argued similarly that the Board should order employers guilty of bad-faith bargaining to "compensate each of its employees for the monetary value during the period of the unlawful refusal to bargain of such additional wage and related benefits as it is reasonable to conclude the union could have obtained through bargaining." with the Board's order, the additional penalty could be imposed.

The penalty would have two basic parts: first, reimbursement of the net back pay accumulated by employees from the date of their rejected application for reinstatement; and second, reimbursement of the amount the employees might have received had the employer originally bargained in good faith. The estimated wage increase could be applied from the date of the unfair labor practice charge.

How would this latter amount be determined ${ }^{37}$ If this penalty were to be applied, the Board would have to identify a set of firms similar to the one in question which were organized by similar unions at the time the union made the bad-faith charge. The Board would compare wage increases in this group with wage increases in another group of similar unorganized firms over the same time period. The mean wage and fringe differences, if any, would be an additional penalty. The practicality of this approach leaves a good deal to be desired. Moreover, it would create an administrative nightmare. Even if one had some general estimate of the impact of unions on wages, it seems unreasonable to give

\footnotetext{
${ }^{37}$ The UAW's brief in the Ex-Cell-O case points up the difficulty of estimating the economic impact of unionism. There is a calculation of the average wage and fringe difference before and after a union contract for sixty-six UAW unions certified by the Board between April and September 1966. These values may be inadequate estimates of the penalties to be applied to employers bargaining in bad faith for at least two reasons. First, there is no classification of firms by size, geographic location, industry, profits, technology, and market structure, viz some correlates of bargaining power. As such the wage increase ranges from $7 \mathrm{c} / \mathrm{hr}$. to $45 \mathrm{c} / \mathrm{hr}$. Second, there is no control, so there is no way of knowing what the wage increases were like for a similar sample of firms which were not organized by UAW unions between April and September 1966.
} 
to a particular union all the gains that other unions obtained over many years of bargaining.

It seems more practical to offer a somewhat different recommendation. Rather than add to back pay the amount the employees might have received if the employer had bargained in good faith, it would be simpler to fine the employer from the date of the unfair labor practice charge. The amount of the fine could be the average wage gain obtained by unions in a relevant industry during negotiations which took place around the time of the unfair labor practice charge. However, this fine would not be an estimate of the amount employees might have received if the employer had bargained in good faith. It simply would be a fine. This may be a dubious distinction, but it may soften criticism of the recommendation as well as make it academically palatable.

Moreover, it is also recommended that the Board, in setting the fine, be free to consider other relevant factors. For example, the Board could adjust upward or downward the level of the penalty according to whether the employer was a first-time offender or a flagrant violator of the law. In addition, the Board might consider changes in the cost of living, adjusting the amount of the fine to reflect changes in the Consumer Price Index.

\section{Modifications to the Reinstatement and Back-Pay Remedy}

Two additional modifications in the reinstatement and back-pay remedy are also recommended.

(1) The Board should modify the requirement that strikers make an unconditional application for reinstatement. Strikers should be permitted to add to their application the "condition" that the employer obey the Board's order to bargain in good faith. If this rule had been applied in the Kohler case, it would have resulted in about one and one-quarter years of additional back pay for about 150 workers who refused Kohler's offer in 1960 because the company was not bargaining in good faith.

(2) The Board should require that the employer make explicit and concrete offers of reinstatement. Many strikers returned to Kohler in 1960 without knowing that the company had cut the workweek to thirty-two hours. The Board should require that the company's offer contain the exact job, shift, hours, rate of pay, and other relevant conditions of employment.

This proposed remedy could have unintended results. That is, increasing the costs of bad-faith bargaining may not necessarily stimulate good-faith bargaining. What may occur is more sophisticated bad-faith bargaining (which could be extremely difficult to prove). The application of our remedy also may lead to increased involvement by the Board in the collective bargaining process and therefore to increased legalism in section $8(a)(5)$ cases.

Is there another way to promote positive collective bargaining? Suppose there were no Board, no third party to turn to in these kinds of bargaining disputes. Would the UAW, under these circumstances, have mounted a more effective strike? Could it have forced Kohler to bargain in good faith before 1962? Would the resolution of this conflict by raw power have satisfied congressional intent as reflected in the NLRA? If the answers to these questions are yes, would the elimination of section $8(a)(5)$ be a better way to promote and encourage 
positive collective bargaining than by "tinkering with the existing remedy"? Eliminating section $8(a)(5)$ is a drastic step and one which is hard to recommend in the absence of conclusive findings about the consequences of such a move.

Section 10(c) of the Act gives the Board broad remedial powers and "charges the Board with the task of devising remedies to effectuate the policies of the Act." 39 Philip Ross has said,

The major shortcoming of the NLRB lies in its failure to adopt adequate and realistic remedies in those cases where the employer has unmistakably demonstrated a continuing intent to frustrate the Act. ${ }^{40}$

Moreover, "The detection of unfair practices means little if the only sanction is social embarrassment. The NLRB's challenge... is the formation of specific, yet flexible orders that give coordinated effect to the Act." 41 Our recommendation is certainly in accord with current legal thinking.

\footnotetext{
${ }^{28}$ The idea of eliminating section $8(a)(5)$ was enunciated by an Independent Study Group in The Public Interest in National Labor Policy (New York: Committee for Economic Development, 1961), pp. 82-83. Professor Douglass V. Brown in a recent talk at the State University of New York at Buffalo (April 25, 1968) suggested some persuasive arguments for the elimination of section $8(\mathrm{a})(5)$. Moreover, the fear of excessive "legalism" was expressed most succinctly by John Dunlop in his 1960 presidential address before the Industrial Relations Research Association, "Consensus and National Labor Policy," Proceedings of the Thirteenth Annual Meeting of the Industrial Relations Research Association, 1960, pp. 2-15.

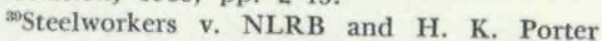
Company, Inc., v. NLRB, District of Columbia Court of Appeals. See Daily Labor Report (Washington: BNA, Dec. 14, 1967), No. 242, full text section. Also, see NLRB v. Seven-Up Bottling Co., 344 U. S. 344 (1953).

${ }^{\circ}$ Philip Ross, The Labor Law in Action (Washington: NLRB, 1966), pp. 1-33.

"Dennis M. Flannery, "The Need for Creative Orders Under Section 10(c) of the National Labor Relations Act," Pennsylvania Law Review, Vol. 112, 1963, p. 94 .
}

\section{Conclusion}

The authors believe their recommendation is reasonable for at least two reasons. First, the empirical evidence presented in this article shows that those most likely to benefit from the reinstatement-back-pay remedy are the more disadvantaged members of the work force. Their recommendation more nearly achieves the goal of truly making the workers "whole" for wrongs committed by their employer. Second, it is supported by collective bargaining theory.

It may be argued that this recommendation alters the power balance between the parties. And it does! The Board, however, has been doing this for years. Back pay is a cost to the employer and altering costs alters the balance of power between the negotiating parties. Consider the following argument. Neil Chamberlain defines the bargaining power of $\mathrm{A}$ as the cost to $\mathrm{B}$ of disagreeing on $\mathrm{A}$ 's terms relative to the costs of $\mathrm{B}$ of agreeing on A's terms, ${ }^{42}$ Following Pao Lun Cheng in the case under discussion, let $w_{1}$ represent Kohler's bargaining offer package, $w_{j}$ represent the UAW's bargaining demand package, and $\mathrm{v}$ represent the strike. ${ }^{43}$ Each package and the strike have some utility to each side and can be represented in terms of utility. If Kohler refused the union's demand, its cost in terms of utility is $u_{k}\left(w_{j}\right)-u_{k}(v)$; and if it agrees, its cost is $u_{k}\left(w_{i}\right)-u_{k}$ $\left(w_{j}\right)$.

${ }^{4}$ Neil W. Chamberlain, Collective Bargaining (New York: McGraw-Hill, 1951), pp. 220-221.

${ }^{4}$ The notation and following argument is based on Pao Lun Cheng's article, "Wage Negotiation and Bargaining Power," Industrial and Labor Relations Review, Vol. 21, No. 2 (January 1968), pp. 163-182. This is an especially good article on bargaining theory. 
By Chamberlain's definition, then, the bargaining power of the union would be

$$
\mathrm{U}_{\mathrm{bp}}=\frac{\mathrm{u}_{\mathrm{k}}\left(\mathrm{w}_{\mathrm{j}}\right)-\mathrm{u}_{\mathrm{k}}(\mathrm{v})}{\mathrm{u}_{\mathrm{k}}\left(\mathrm{w}_{\mathrm{i}}\right)-\mathrm{u}_{\mathrm{k}}\left(\mathrm{w}_{\mathrm{j}}\right)} .
$$

Similarly, if the UAW rejects Kohler's offer, the cost is $u_{a}\left(w_{i}\right)-u_{a}(v)$; if it accepts, the cost is $u_{a}\left(w_{j}\right)-u_{a}\left(w_{i}\right)$.

Therefore, Kohler's bargaining power is given by

$$
K_{b p}=\frac{u_{a}\left(w_{i}\right)-u_{a}(v)}{u_{a}\left(w_{j}\right)-u_{a}\left(w_{i}\right)}
$$

It is worthwhile considering the implications of this formulation of relative bargaining power, since, as Cheng has demonstrated, there is "substantial similarity in the explicit or implicit definitions of bargaining power among Chamberlain, Pen, and Harsanyi-Zeuthen. ..."44

If $\mathrm{K}_{\mathrm{bp}}$ is greater than $\mathrm{U}_{\mathrm{bp}}$ by virtue of the commission of certain unfair labor practices, then a public policy remedy should either (1) decrease Kohler's bargaining power and consequently increase the union's, or (2) increase the union's bargaining power, thereby decreasing Kohler's. How can this be done? It is not likely that the Board could alter $\mathrm{w}_{\mathrm{i}}$ or $\mathrm{w}_{\mathrm{j}}$. If it could, it is unlikely that such manipulation would be appropriate for the Board. The only arbitrarily manipulable term in the inequality is the cost of a strike. If the back pay for which the employer is liable is increased, the cost of a strike to the employer is increased and its associated utility, $\mathrm{u}_{\mathrm{k}}(\mathrm{v})$, decreases, thus increasing $U_{b p}$. By the same logic, the utility of a strike for the union, $u_{a}(v)$, increases, and $\mathbf{K}_{\mathrm{bp}}$ falls.

It also seems reasonable to argue that the duration of an unfair labor practice strike is a function of the relative power of each side. If $\mathrm{K}_{\mathrm{bp}}<\mathrm{U}_{\mathrm{bp}}$, the duration

\footnotetext{
MIbid., p. 167.
}

of an employer unfair labor practice strike would be short. But in this case, the power differential, $\mathrm{K}_{\mathrm{bp}}>\mathrm{U}_{\mathrm{bp}}$, was quite large. The authors' recommendation would lessen it and hopefully reduce the propensity for an employer with large advantages over the union to engage in bad-faith bargaining.

It might also be noted that such a penalty is likely to be imposed only in first bargaining cases. Philip Ross found that most of the $8(a)(5)$ charges occurred in negotiations over the first contract when the employer was still fighting the entire idea of bargaining. ${ }^{45}$ After one contract, the frequency of bad-faith bargaining decreases drastically and section $8(a)(5)$ may become irrelevant. After the first contract, therefore, it may be sensible to let pure power decide these issues. ${ }^{46}$ Section $8(a)(5)$ is less applicable to bargaining situations with some experience, but when it is applicable, the bad-faith bargaining may be very subtle and hard to discern.

Clearly, more severe costs could be imposed, but why jump to a harsh penalty? It is more sensible to escalate the remedy gradually while testing the impact of each escalation. This testing is very necessary since there is no point in constructing remedies if they do not work or if they work in an unexpected fashion. The only guideline is that "the order [should not be] a patent attempt to achieve ends other than those which can fairly be said to effectuate the policies of the Act." ${ }^{* 7}$ It is believed this recommendation is within this prescript.

\footnotetext{
${ }^{45}$ Ross, op. cit., pp. 1-33.

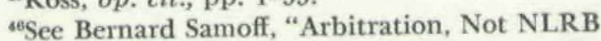
Intervention," Labor Law Journal, Vol. 18, No. 10 (October 1967), pp. 602-631.

"Virginia Electric \& Power Co. v. Labor Board, 319 U.S. 533, 540 (1941). Fibreboard Paper Products Corp. v. NLRB, 379 U.S. 203, 216 (1964).
} 
Copyright of Industrial \& Labor Relations Review is the property of Cornell University. The copyright in an individual article may be maintained by the author in certain cases. Content may not be copied or emailed to multiple sites or posted to a listserv without the copyright holder's express written permission. However, users may print, download, or email articles for individual use. 